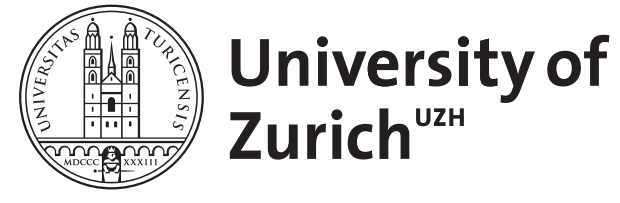

\title{
Clay jojoba oil facial mask for lesioned skin and mild acne - results of a prospective, observational pilot study
}

\author{
Meier, L ; Stange, R ; Michalsen, A ; Uehleke, B
}

DOI: https://doi.org/10.1159/000338076

Posted at the Zurich Open Repository and Archive, University of Zurich ZORA URL: https://doi.org/10.5167/uzh-66594

Journal Article

Published Version

Originally published at:

Meier, L; Stange, R; Michalsen, A; Uehleke, B (2012). Clay jojoba oil facial mask for lesioned skin and mild acne - results of a prospective, observational pilot study. Forschende Komplementärmedizin, 19:75-79.

DOI: https://doi.org/10.1159/000338076 


\title{
Clay Jojoba Oil Facial Mask for Lesioned Skin and Mild Acne - Results of a Prospective, Observational Pilot Study
}

\author{
Larissa Meier $^{a}$ Rainer Stange ${ }^{a}$ Andreas Michalsen ${ }^{a} \quad$ Bernhard Uehleke $^{a, b}$ \\ a Immanuel Hospital, Department of Complementary and Integrative Medicine, Charité University Medical Centre, \\ Institute for Social Medicine, Epidemiology and Health Economics, Germany \\ ${ }^{\mathrm{b}}$ Institute of Complementary Medicine, Department of Internal Medicine, University Hospital Zürich, Switzerland
}

\section{Key Words}

Postadolescent acne - Pre-acne - Skin lesions - Facial mask . Medical clay · Jojoba oil · Pilot study

\section{Summary}

Background: External application of clay facial masks is a cosmetic procedure generally used to reduce skin lesions and to improve overall skin condition. Objective: Collecting pilot data about self-treatment with clay jojoba oil masks on participants with acne-prone, lesioned skin and acne. Methods: Open, prospective, observational pilot study: Participants received written information, instructions, and questionnaires without direct contact with the study physician. For 6 weeks, they applied the masks 2-3 times per week. The primary outcome is the difference of skin lesions: baseline vs. after 6 weeks. Results: 194 participants (192 female, 2 male, mean age $( \pm \mathrm{SE})(32.3 \pm 0.7$ years $)$ returned questionnaires and diaries. 133 of these participants returned complete and precise lesion counts (per-protocol (PP) collective). A $54 \%$ mean reduction in total lesion count was observed after 6 weeks of treatment with clay facial mask. Both inflammatory and non-inflammatory skin lesions were reduced significantly after treatment compared to baseline: Median counts (MC) of pustules per affected participant were reduced from $7.0 \pm 0.9$ to $3.0 \pm 0.5$ (mean individual reduction $(\mathrm{MIR})=49.4 \%)$, the $\mathrm{MC}$ of the papules from $3.5 \pm$ 2.2 to $1.0 \pm 0.4$ (MIR $=57.3 \%$ ), the $\mathrm{MC}$ of cysts from $2.0 \pm 0.8$ to $0.5 \pm 0.4$ ( $\mathrm{MIR}=68.6 \%$ ) and the $\mathrm{MC}$ of comedones from $26.5 \pm 6.3$ to $16.0 \pm 4.0$ (MIR = 39.1\%). DLQl-average score decreased from $5.0 \pm 4.5$ (mean \pm SE) before to $2.1 \pm 2.8$ after treatment. Conclusions: The present study gives preliminary evidence that healing clay jojoba oil facial masks can be effective treatment for lesioned skin and mild acne vulgaris.

\section{Schlüsselwörter}

Akne · Prä-Akne · Hauteffloreszenzen · Gesichtsmaske · Heilerde · Jojobaöl · Pilotstudie

\section{Zusammenfassung}

Hintergrund: Die externe Anwendung von Heilerde-Gesichtsmasken ist ein kosmetisches Verfahren, das in der Regel verwendet wird, um Hauteffloreszenzen zu reduzieren und das gesamte Hautbild zu verbessern. Ziel: Erfassen primärer Daten über die Selbstbehandlung mit Heilerde-Gesichtsmasken mit Jojobaöl bei Teilnehmern mit unreiner Haut, Hauteffloreszenzen und Akne. Methoden: Offene, prospektive, empirische Pilotstudie: Die Teilnehmer erhielten schriftliche Informationen, Anleitungen und Fragebögen ohne direkten Kontakt zum Prüfarzt. 6 Wochen lang haben die Teilnehmer die Masken zwei- bis dreimal pro Woche angewendet. Der primäre Zielparameter ist die Differenz von Hauteffloreszenzen: Baseline gegenüber nach 6 Wochen. Ergebnisse: 194 Teilnehmer (192 weiblich, 2 männlich, mittleres Alter ( \pm Standardfehler) $(32,3 \pm 0,7$ Jahre $)$ haben die Fragebögen und Tagebücher zurückgeschickt. 133 dieser Teilnehmern haben die Hauteffloreszenzen vollständig und sehr präzise dokumentiert (Per-Protokoll(PP)-Kollektiv). Eine $54 \%$ ige mittlere Reduktion der gesamten Effloreszenzen wurde nach 6 Wochen der Behandlung mit der HeilerdeGesichtsmaske beobachtet. Im Vergleich zur Baseline ging sowohl die Anzahl der entzündlichen als auch die der nichtentzündlichen Effloreszenzen signifikant zurück: der Median (M) für Pusteln pro betroffenen Teilnehmer wurde von 7,0 \pm 0,9 auf $3,0 \pm 0,5$ reduziert (mittlere individuelle Reduktion $(\mathrm{MIR})=49,4 \%)$, der $\mathrm{M}$ für Papeln von 3,5 $\pm 2,2$ auf 1,0 $\pm 0,4$ (MIR $=57,3 \%$ ), der M für Zysten von 2,0 $\pm 0,8$ auf 0,5 $\pm 0,4$ (MIR $=68,6 \%$ ) und der M für Komedonen von 26,5 $\pm 6,3$ auf $16,0 \pm 4,0$ (MIR = 39,1\%). Der DLOI-Score sank von 5,0 $\pm 4,5$ vor der Behandlung auf 2,1 $\pm 2,8$ nach der Behandlung. Schlussfolgerungen: Die vorliegende Studie gibt erste Hinweise über die mögliche Wirksamkeit von HeilerdeGesichtsmasken mit Jojobaöl bei der Behandlung unreiner Haut und milder Akne vulgaris.

\section{KARGER \\ Fax +497614520714 \\ Information@Karger.de}

www.karger.com (c) 2012 S. Karger GmbH, Freiburg

$1661-4119 / 12 / 0192-0075 \$ 38.00 / 0$

Accessible online at:

www.karger.com/fok
Prof. Dr. med. Dr. rer. nat. Bernhard Uehleke

Immanuel Hospital, Department of Complementary and Integrative Medicine

Charité University Medical Centre, Institute for Social Medicine, Epidemiology and Health Economics

Königstraße 63, 14109 Berlin, Germany

+49 30 80505-691, Fax -692

b.uehleke@immanuel.de 


\section{Introduction}

Acne-prone, lesioned skin is the result of excessive sebum production, bacterial settlement and inflammation. Dilated pores, oily and uneven skin and inflammatory and noninflammatory skin lesions are characteristic for lesioned skin and acne [1]. Acne is one of the most common dermatologic diseases and is generally present in adolescent patients [2]. However, epidemiological studies have shown that a significant population of female patients $>25$ years old have acne, and this number has increased over the past 10 years [3]. A community-based UK study estimated the prevalence of facial acne to be $14 \%$ in women between the ages of 26 and 44 years [4]. There are a lot of acne grading systems. In this pilot study we used the classification by Plewig and Kligman [2]. Causes for lesioned skin and other acne-like conditions in post-adolescent patients may come from metabolic and hormonal imbalances, endocrine abnormalities, use of cosmetics, nicotine, infections and immunological diseases [5, 6].

The conventional therapy includes topical and systemic retinoids, antibiotics and anti-androgens depending on severity [7]. Frequently used complementary and alternative treatment methods include jojoba wax, green tea, tea tree oil, etc. [8-10]. Light therapy may also reduce skin lesions [11, 12].

The medical clay consists of fine mineral particles and trace elements that have both adsorptive and absorptive properties. Organic and inorganic substances are easily bound by hydrogen bonds and Van der Waals forces. Healing clay can be used both internally and externally. It is an effective treatment for knee osteoarthritis [13], dermatological problems (external use) [14] and constipation-predominant irritable bowel syndrome [15] (internal use). The healing clay comes from distinct regions in Germany.

Ready-to-use facial mask with healing clay and jojoba oil is recommended for oily, acne-prone, and lesioned skin. The benefits of clay masks come mainly from their drying effects. This produces a substantial absorptive effect, which triggers a flow of fluid from the inside outwards. This flow transports metabolic products, cellular particles and bacterial toxins away from the skin and causes them to bind to the healing clay ('detoxification'). The fine clay particles absorb excessive

Fig. 1. Differentiation and skin lesions counts (CRF). The face fielded in five locations. The borders on the face are delineated by the hairline, jawline, and ears. After skin lesion differentiation and counting, the participants were asked to register the findings in there CRFs before the first intervention and after the last one.

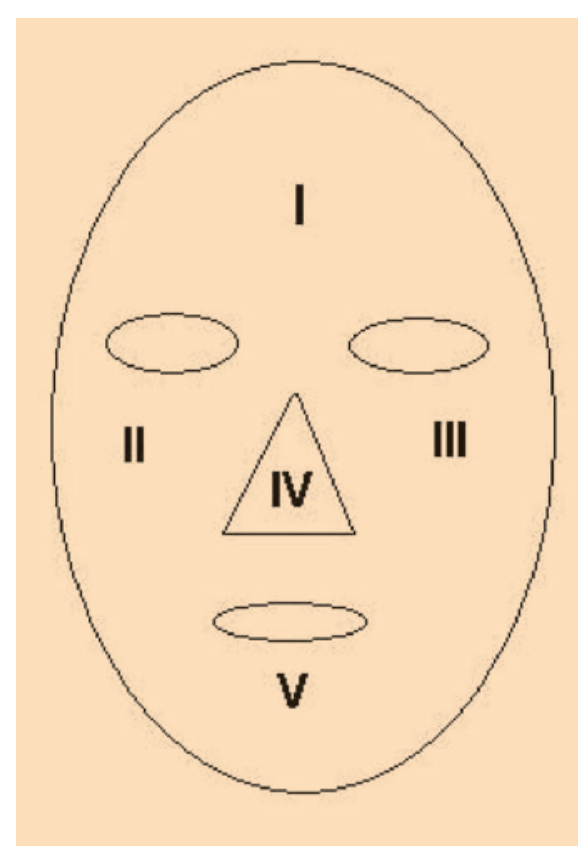

Table 1. Patient characteristics

Table 2. Acne classification (Plewig and Kligman) according to self-reported data $(\mathrm{n}=133)$

\begin{tabular}{|c|c|c|c|c|c|c|}
\hline \multirow[t]{2}{*}{ Participants } & \multicolumn{3}{|c|}{ ITT $(\mathrm{n}=194)$} & \multicolumn{3}{|c|}{$\mathrm{PP}(\mathrm{n}=133)$} \\
\hline & mean & range & SE & mean & range & SE \\
\hline Age, years & 32.3 & $17-60$ & 0.7 & 31.4 & $18-60$ & 0.8 \\
\hline Height, m & 1.7 & $1.5-1.9$ & 0.01 & 1.69 & $1.5-1.9$ & 0.01 \\
\hline Weight, kg & 66.4 & $44-110$ & 0.9 & 66.5 & $44-110$ & 1.0 \\
\hline Body mass index, $\mathrm{kg} / \mathrm{m}^{2}$ & 23.3 & $14.5-39.8$ & 0.3 & 23.2 & $16.7-39.2$ & 0.3 \\
\hline Mean duration of lesioned skin, years & 15.8 & $1-46$ & 0.7 & 14.7 & $1-46$ & 0.8 \\
\hline
\end{tabular}

\begin{tabular}{|c|c|c|c|c|c|c|c|c|c|}
\hline Numbers & \multicolumn{4}{|c|}{ Comedonal acne } & \multicolumn{4}{|c|}{ Papulopustular acne } & $\begin{array}{l}\text { Lesioned skin ( } \leq 5 \text { skin lesions } \\
\text { per half of face) }\end{array}$ \\
\hline Absolute & \multicolumn{4}{|l|}{40} & \multicolumn{4}{|l|}{66} & 27 \\
\hline \multirow[t]{4}{*}{ Relative (\%) } & \multicolumn{4}{|l|}{30.1} & \multicolumn{4}{|l|}{49.6} & 20.3 \\
\hline & \multicolumn{4}{|c|}{ Comedonal acne } & \multicolumn{4}{|c|}{ Papulopustular acne } & \\
\hline & \multicolumn{4}{|c|}{ grade } & \multicolumn{4}{|c|}{ grade } & \\
\hline & I & II & III & IV & I & II & III & IV & \\
\hline Absolute & 12 & 5 & 7 & 6 & 44 & 14 & 4 & 4 & \\
\hline Relative (\%) & 9.0 & 11.3 & 5.3 & 4.5 & 33.1 & 10.5 & 3 & 3 & \\
\hline
\end{tabular}




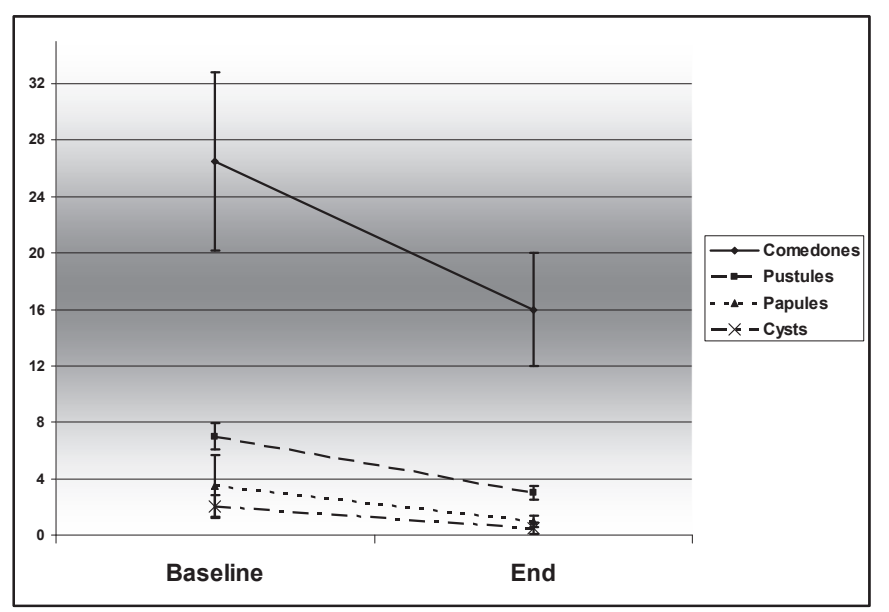

Fig. 2. Skin lesion counts by skin lesion type (median at baseline vs. end).

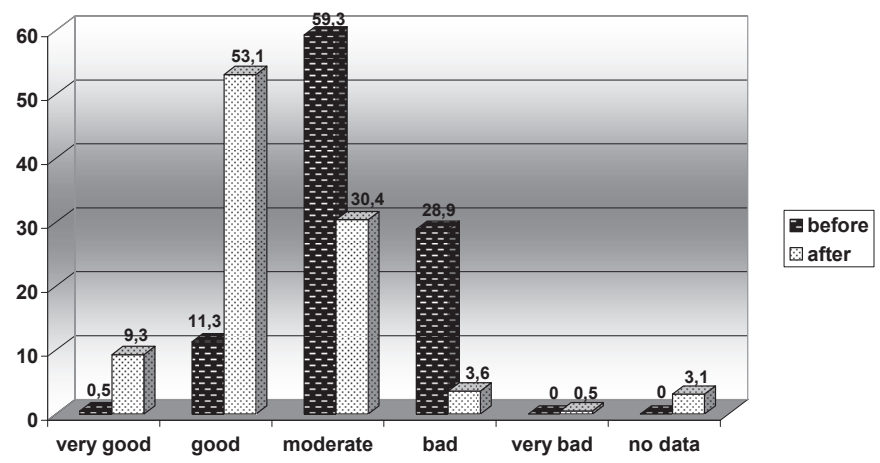

Fig. 3. Skin condition in \% (baseline vs. end).

amounts of sebum, clean the pores and remove impurities from the skin [16-18]. Blood flow is enhanced, and supply of oxygen and nutrients to the skin is improved [19]. In addition, jojoba oil Simmondsia chinensis, an ingredient in the clay facial mask, has anti-inflammatory and antibacterial effects and is effective in the treatment of acne in previous studies [8]. However, some studies of clay/mud for dermatological problems have shown significant corelation between clay masks and acne and thermal mud baths and seborrheic dermatitis [20, 21].

We aimed to generate pilot data of the effectiveness on clay jojoba oil mask therapy under daily life condition.

\section{Methods}

In order to generate the pilot data about clay jojoba oil masks in acneprone and lesioned skin, we performed a prospective pilot study. Participants received written information and instructions and were asked to complete questionnaires and document symptoms. Study materials (clay jojoba oil masks which were available on the market, questionnaires, instructions) were distributed by mail to 200 interested participants who responded to an article in a health journal. In addition, we asked for medical history information in our questionnaires. As no contraindications are known for clay treatment no specific exclusion criteria had to be defined.

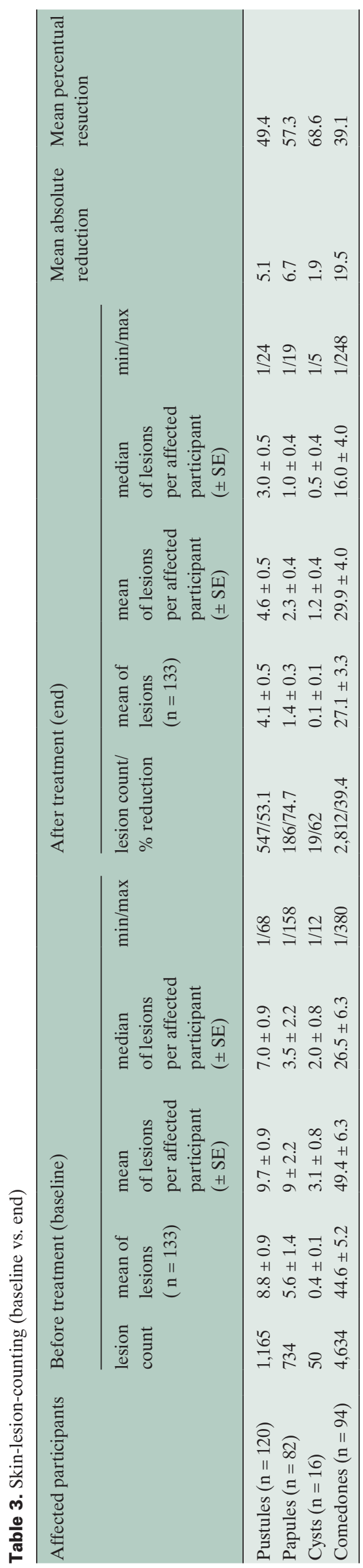


The treatment consisted of a series of mask applications over 6 weeks. Participants were asked to apply the mask 2-3 times a week all over their face sparing the eye and mouth areas and to remove it after 15-20 min with water or a soft facial tissue. The participants were asked to count and to type their skin lesions. They received the instructions about skin lesions/differentiation [22] and skin lesion counting (fig. 1).

Additional questions asked participants about demographics, general well-being, history and aetiology of skin conditions, and other diseases We also used the Dermatology Life Quality Index questionnaire (DLQI) to evaluate the impact of skin diseases on different aspects of their life [24]. Data were analysed descriptively. T-test was used and paired if appropriate. The primary outcome measure was change in skin lesion counts: baseline versus the end of the treatment period ( 6 weeks). Further predefined outcome measure was quality of life score (DLQI) before and after treatment, number of mask applications and skin condition. We received written informed consent for using pseudonymised data for statistical evaluations from all participations.

\section{Results}

Out of 200 mailings, questionnaires from 194 participants (mean age $32.4 \pm 0.7$ years) were returned. A completed diary was obtained from 194 participants. Of these 194 questionnaires, 133 were fully completed and could be entered into statistical analysis. Mean duration of lesioned skin was 15.8 years. $70 \%$ of participants were non-smokers. The self-reported causes for skin lesions were psychosocial stress $78.4 \%$, chocolate $38.1 \%$, solar irritation $13.4 \%$, normonal contraceptives $12.9 \%$ and chemical agents $9.3 \%$. The application of the clay mask was easy to handle for most participants. 133 participants returned completed counts of their skin lesions. We focussed our analysis on this per-protocol (PP) collective of participants. There was no relevant difference in demographic data between the PP collective and the intention-to-treat (ITT) collective as shown in table 1. According to lesion counts, $79.8 \%$ of the PP participants could be classified as having acne, most of them with grade I papulopustular acne according to Plewig and Kligman(table 2).

$43.6 \%$ of the PP collective reported having one or more concomitant or prior dermatologic diagnoses: $35.3 \%$ - acne vulgaris, $6.0 \%$ - other skin diseases such as rosacea or atopic dermatitis, and $2.3 \%$ - both acne and other dermatologic diseases.

Of the 133 PP participants (i.e. those who counted lesions precisely) both inflammatory and non-inflammatory skin lesions were reduced significantly after treatment compared to baseline as can be seen in figure 2 and table 3. A 54\% (PP col- lective) mean reduction in total lesion count was observed after 6 weeks of treatment with clay facial mask. Average score of the DLQI decreased from $4.0 \pm 0.4(\mathrm{M} \pm \mathrm{SE})$ before treatment to $1.0 \pm 0.2$ after treatment. Almost all participants reported complying with a mean application of 2.4 times per week. The mean duration of the mask application was 15.6 min, slightly longer than of the recommended 10-15 min. $13.5 \%$ of participants reported difficulties with the application of the mask. $67.7 \%$ washed the mask off with water, and $28.6 \%$ peeled off the dried mask without water. Skin feeling was rated 'good' on average during applications $(\mathrm{M}=2.3 ; 1-5$ Likert scale, 1 = very good to $5=$ very bad) as well as afterwards $(M=2.0)$. Skin dryness (xerosis) did not change significantly during the course of the study, but general skin condition improved significantly (fig. 3). Accordingly, about $80 \%$ of the participants $(n=194)$ rated skin sensation and effectiveness of the mask as good or very good.

\section{Discussion}

Results of this study show that treatment with clay jojoba oil facial masks can reduce pustules, papules, cysts, and comedones as well as the impact of dermatological conditions on quality of life. These results are consistent with studies of conventional therapies such as oral and topical antibiotics [25, 26]. The pilot study is a pragmatic, cost-effective study design for collecting preliminary data about self-treatments. However, these study results are limited by design and quality. The participants had to type and count the skin lesion by themselves. There were a lot of misunderstandings in interpretation of the returned lesion-count-diaries, what has contributed to increase in dropout rate. In conclusion, the present study gives preliminary evidence that healing clay jojoba oil facial masks can be an effective treatment for lesioned skin and mild acne vulgaris.

\section{Disclosure Statement}

The study was sponsored by Heilerde-Gesellschaft Luvos Just GmbH \& Co. KG, Friedrichsdorf, Germany, manufacturer of healing clay products and clay jojoba oil facial mask (Luvos-Heilerde Gesichtsmaske), used in this study. In addition, Bernhard Uehleke has received payments by this company for giving lectures on clay.

\section{References}

1 Leitlinie der Gesellschaft für Dermatopharmazie 2005: www.gd-online.de/german/veranstalt/images2005/ Dermokosmetika_zur_Pflege_der_Aknehaut.pdf.

2 Plewig G, Kligman AM: Acne and Rosacea. Heidelberg, Springer, 2000.

3 Goulden V, Clark SM, Cunliffe WJ: Post-adolescent acne: a review of clinical features. Br J Dermatol 1997;137:478-9.
4 Williams C, Layton AM: Persistent acne in women: implications for the patient and for therapy. Am J Clin Dermatol 2006;7:281-90.

5 Aizawa H, Niimura M: Adrenal androgen abnormalities in women with late onset and persistent acne. Arch Dermatol Res 1993;284:451-5.

6 Capitanio B, Sinagra JL, Ottaviani M, Bordignon $\mathrm{V}$, et al.: Acne and smoking. Dermatoendocrinology 2009;1:129-35.
7 Zouboulis CC, Piquero-Martin, J: Update and future of systemic acne treatment. Dermatology 2003;206:37-53.

8 Habashy RR, Abdel-Naim AB, Khalifa AE, AlAzizi MM: Anti-inflammatory effects of jojoba liquid wax in experimental models. Pharmacol Res 2005;51:95105. 
9 Elsaie ML, Abdelhamid MF, Elsaaiee LT, Emam HM: The efficacy of topical $2 \%$ green tea lotion in mild-to-moderate acne vulgaris. J Drugs Dermatol 2009;8: $358-64$

10 Raman A, Weir U, Bloomfield SF: Antimicrobial effects of tea-tree oil and its major components on Staphylococcus aureus, Staph. epidermidis and Propionibacterium acnes. Lett Appl Microbiol 1995;21:242-5.

11 Choi YS, Suh HS, Yoon MY, Min SU, Lee DH, Suh DH: Intense pulsed light vs. pulsed-dye laser in the treatment of facial acne: a randomized split-face trial. J Eur Acad Dermatol Venereol 2010;24:773-80.

12 Kawana S, Tachihara R, Kato T, Omi T: Effect of smooth pulsed light at 400 to 700 and 870 to $1,200 \mathrm{~nm}$ for acne vulgaris in Asian skin. Dermatol Surg 2009;36: $52-7$.

13 Odabasi E, Turan M, Erdem H, Tekbas F. Does mud pack treatment have any chemical effect? A randomized controlled clinical study. J Altern Complement Med 2008;14:559-65.

14 Comacchi C, Hercogova J: A single mud treatment induces normalization of stratum corneum hydration, transepidermal water loss, skin surface $\mathrm{pH}$ and sebum content in patients with seborrhoeic dermatitis. J Eur Acad Dermatol Venereol 2004;18:372-4.

15 Ducrotte P, Dapoigny M, Bonaz B, Siproudhis L. Symptomatic efficacy of beidellitic montmorillonite in irritable bowel syndrome: a randomized, controlled trial. Aliment Pharmacol Ther 2005;21:435-44.

16 Ducrotte P, Dapoigny M, Bonaz B, Siproudhis L: Symptomatic efficacy of beidellitic montmorillonite in irritable bowel syndrome: a randomized, controlled trial. Aliment Pharmacol Ther 2005;21:435-44

17 Herrera P, Burghardt RC, Phillips TD: Adsorption of Salmonella enteritidis by cetylpyridinium-exchanged montmorillonite clays. Vet Microbiol 2000;74:259-72.

18 www.luvos.de/content.asp?lid $=1 \&$ sdid $=0 \&$ did $0=2 \&$ did $1=10 \&$ wptid $=1 \&$ wpid $=14$ $\&$ mid $=0 \&$ ptid $=\&$ pid $=0 \&$ sid $=0$.

19 Poensin D, Carpentier PH, Féchoz C, Gasparini S: Effects of mud pack treatment on skin microcirculation. Joint Bone Spine 2003;70:367-70.

20 Gönül M, Gül U, Cakmak SK, Kiliç S: Unconventional medicine in dermatology outpatients in Turkey. Int J Dermatol 2009;48:639-44.

21 Carabelli A, De Bernardi di Valserra G, De Bernardi di Valserra M, Tripodi S et al.: Effect of thermal mud baths on normal, dry and seborrheic skin. Clin Ter 1998;149:271-5.

22 Fitzpatrick TB, Johnson RA, Wolff K et al.: Fitzpatrick's color atlas and synopsis of clinical dermatology. New York, McGraw-Hill Medical, 2009

23 Finlay AY, Khan GK: Dermatology Life Quality Index (DLQI) - a simple practical measure for routine clinical use. Clin Exp Dermatol 1994;19:210-6.

24 Department of Dermatology and Wound Healing: Quality of life and DLQI: www.dermatology.org.uk.

25 Gold MH: A multicenter efficacy and tolerability evaluation of benzoyl peroxide in a $10 \%$ urea vehicle for the treatment of acne vulgaris. J Drugs Dermatol 2006;5:442-5.

26 Green LJ, Del Rosso JQ: Efficacy and tolerability of a three-step acne system containing a solubilized benzoyl peroxide lotion versus a benzoyl peroxide /clindamycin combination product: an investigator-blind, randomized, parallel-group study. J Clin Aesthet Dermatol 2008;1:16-20. 